\title{
POLITICS AND PLAY IN THE LAVS PISONIS*
}

\begin{abstract}
This article examines the first-century C.E. Laus Pisonis, an anonymous panegyric for a certain Piso that lays particular emphasis on his skill at lyre-playing, ball games and the board game, the ludus latrunculorum (155-210). Whereas this focus has often been a cause of consternation among critics, this article argues that play is a crucial element of the poem's poetic and political operations. The first section shows that the poem employs images of poetic maturity and of temporality in order to justify a light or ludic topic for an allegedly young poet. The second section identifies a hitherto unobserved telestich (M-O-R-A) in the passage describing the ludus latrunculorum and argues that this letter game defines a positive period of play within the poem. The third section further demonstrates that this letter game is aimed specifically at the patron Piso as he is represented within the poem. That is, the poet parallels Piso's potential to uncover the telestich in the text and his ability to uncover the poet's hidden talent. The concluding fourth section explores the wider impact of this reinterpretation of the Laus Pisonis for the literary history of the Early Principate. It proposes that the poem's playfulness should not be seen as reflecting the progressive disempowerment of the political elite. Rather, the poem is an early case of Roman political discourse encroaching on the value of the trivial and the boundaries of otium. The Laus Pisonis makes play political.
\end{abstract}

Keywords: praise; Piso; panegyric; patronage; play; wordplay; ludus

A panegyric for a patron is supposed to be a serious thing: it is the currency supporting the commerce between patron and client. Both expect to gain a greater public profile through such compositions: the poet displays his skills and the patron is represented as worthy of praise and a wielder of power. But must such poetry be serious in content, must the topic of discussion be lofty and highbrow? This is precisely the question that confronts the reader of the first-century C.E. Laus Pisonis (henceforth LP), a Latin hexameter panegyric that praises a certain Piso and dramatizes the poet's appeal to him for patronage. ${ }^{1}$ Strikingly, this panegyric does not progress to the pinnacle of the patron's career, pinpoint his political power or military prowess, or else predict such for the future: it turns instead to Piso's skill at lyre-playing, ball games and the board

* I would like to thank Talitha Kearey, Thomas Nelson, $C Q$ 's anonymous readers and its editor, Bruce Gibson, for their valuable comments and suggestions and to thank Tom Geue for sharing work from his book while it was still unpublished. Moreover, I am particularly grateful to Christopher Whitton whose intervention-by asking the right question at the right time-prompted me to transform a short paper into something more ambitious. Translations are my own unless otherwise stated.

${ }^{1}$ The Latin text follows S. Di Brazzano, Laus Pisonis. Introduzione, edizione critica, traduzione e commento (Pisa, 2004), and the translation is taken from J.W. Duff and A.M. Duff, Minor Latin Poets (Cambridge, MA, 1935), 295-315, with minor changes.

(C) The Author(s), 2021. Published by Cambridge University Press on behalf of The Classical Association. This is an Open Access article, distributed under the terms of the Creative Commons Attribution licence (http:// creativecommons.org/licenses/by/4.0/), which permits unrestricted re-use, distribution, and reproduction in any medium, provided the original work is properly cited.. 
game, the ludus latrunculorum (155-210). ${ }^{2}$ The poet may claim to be motivated by a love of praise (laudis amor, 221), but the request for patronage immediately following the image of a draughts-playing Piso places the seriousness of the request into question. Did he expect to be taken seriously with such a manifestly unserious characterization of his patron? Is this all just a game to the poet of the $L P$ ? My intention in this article is to suggest that admitting a little playfulness into the $L P$ does in fact allow for an improved reading of both its poetic and its political operations. So too I seek to redeem the author of the $L P$ as more than simply incapable of following the panegyric paradigm and to reveal instead a poet who takes on the innovative, but also risky, task of intertwining seriousness and play within a praise poem.

Up until now, however, as with so many other anonymous and pseudonymous poems, scholarly interest in the $L P$ has largely centred on issues of date and authorship. ${ }^{3}$ The Piso to whom it is addressed is usually identified as Gaius Calpurnius Piso, described in Tacitus as having led a failed plot against Nero in 65 C.E. (Ann. 15.48). The date of composition is unknown but presumed to be Claudian or Neronian. The author is also unknown: suggestions that it was composed by Lucan and Calpurnius Siculus have found little traction. ${ }^{4}$ Steven Green has taken a particularly historicist approach to the $L P$, proposing a date around 65 C.E., the addressee as Gaius Calpurnius Piso who at the time appeared to be a pretender to Nero's throne, and the poem as a serious attempt to promote Piso as a viable alternative. ${ }^{5}$ The focus on Piso's pastimes, taking up almost as much space as his oratorical abilities, might appear to undermine the poetic bid to cast Piso in a serious light, but, so Green proposes, the poet's use of military language to describe non-military pursuits is an attempt at providing a veneer of competence against the backdrop of a $\mathrm{CV}$ severely lacking in real military involvement. Such a reading, though, results in a poem that singularly fails to sell the qualities of this counterclaimant, because it makes manifest his missing military experience.

A notable exception to the generally pessimistic attitude to the poem's literary merit can be found in the work of Irene Peirano-Garrison. She argues that the author of the $L P$ must be understood as responding to the discourse of poetic patronage explored by the likes of Horace, Martial and Juvenal, and that he does so by playing the role of an

\footnotetext{
${ }^{2}$ Here is the structure of the poem, in brief. The poet opens with a traditional search for a suitable topic and form of praise for the laudandus (1-24), before considering Piso's career as a public speaker and advocate, and his assumption of a consulship (25-80). The poem then turns to Piso's character and virtues such as his oratorical dexterity (84-96) and fine appearance (97-108), and praises his treatment of his clients (109-58). After that the poet addresses Piso's skill at lyre-playing, ball games and the board game, the ludus latrunculorum (155-210). The poet concludes with a request for patronage and a promise to compose further works, presenting Maecenas as the prime model of a patron of the arts (211-61).

${ }^{3}$ Or else scholarship has co-opted it as straightforward evidence for a broader culture of literary patronage in ancient Rome: cf. e.g. J.P. Sullivan, Literature and Politics in the Age of Nero (Ithaca, 1985), 36.

${ }^{4}$ The debate concerning authorship and date go hand in hand. Cf. e.g. B.L. Ullman, 'The text tradition and authorship of the Laus Pisonis', CPh 24 (1929), 109-32, at 130-2; Duff and Duff (n. 1), 289-90 and 209-13; M.D. Reeve, 'The addressee of Laus Pisonis', ICS 9 (1984), 42-8; E. Champlin, 'The life and times of Calpurnius Piso', MH 46 (1989), 101-24; Di Brazzano (n. 1), 47-86. G. Laguna Mariscal, Estacio (Madrid, 1998), 18, 20 suggests in passing that the LP might be an early work of Statius.

${ }^{5}$ S. Green, “"(No) Arms and a man": the Imperial pretender, the opportunistic poet and the Laus Pisonis', CQ 60 (2010), 497-523, at 514-18.
} 
incompetent poet presenting a job application. ${ }^{6}$ Following Peirano-Garrison's work, Tom Geue has recently sought to banish overly historicist approaches to the $L P$, and speculations about the identity of both its author and Piso. He argues instead that the pointed resistance to specifying the Piso addressed and the figure of the poet constitutes a strategy intended to figure the $L P$ as a praise poem suitable for any number of Pisones, occasions and readers: he asks us to adjust our eyes to the poem's purposeful obscurity. ${ }^{7}$ In this article, I build on these readings of the generic awareness of the $L P$ and propose a more earnest reading of the poem, but one that is no less playful. Something more complex is going on than a po-faced panegyric that follows the well-worn poetic path of simultaneously praising a patron and puffing up the poetic profile.

Indeed, rather than treating the non-military aspects of Piso's career as a stumbling block to an interpretation of this praise poem, I want to set the representation of Piso 'the player of games' at the centre of the text's workings. My argument is that the poet is forging a poem that values play, and that he takes particular care to negotiate its status within the traditional strictures of what a poem for a patron should look like. In the first section, I demonstrate how imagery of poetic maturity and poetic temporality is employed to argue for the appropriateness of a light topic for an allegedly young poet within the panegyric genre. In the second section, I show that the passage describing Piso's leisure activities and specifically his playing of the ludus latrunculorum conceals a previously unobserved telestich $(M-O-R-A)$ and that the meaning of this letter game defines a positive period of play within the poem. In the third section, I suggest that both the justification of a lighter topic and the use of letter games are directly connected to his pitch to (a) Piso as his patron. What will emerge is a poem that is deeply aware of the expectations of panegyric but nevertheless chooses to play with the genre, the text and his reader(s). In concluding, I tentatively outline the ramifications of the merging of politics and play in the $L P$ for the history of post-Augustan poetry: the panegyric indicates a new place for poetry within both the otium and the negotium of the Early Principate.

\section{TIME FOR GAMES}

The appropriateness of poetic subject matter in relation to the experience of the poet and to the generic expectations of the audience is a recurring concern for poets. The poet of the $L P$ articulates a particularly novel and targeted sense of this appropriateness in relation to time. The aim, I suggest, is to justify the composition of a playful poem with recourse to pre-existing poetic and cultural images of time and temporality.

Having begun the poem by declaring just how impressive and noble Piso is as a person, the poet turns to reflect on his ability to put such a life into verse. An astronomical concern for the course of the year informs the poet's recusatio (19-22):

et prius aethereae moles circumuaga flammae annua bissenis reuocabit mensibus astra, quam mihi priscorum titulos operosaque bella contigerit memorare.

\footnotetext{
${ }^{6}$ I. Peirano-Garrison, The Rhetoric of the Roman Fake: Latin Pseudepigrapha in Context (Cambridge, 2012), 148-72.

${ }_{7}$ T. Geue, Author Unknown: The Power of Anonymity in Ancient Rome (Cambridge, MA, 2020), 143-63 (ch. 5: 'Poet seeks patron: an open letter from me to you, or numerosa laus').
} 
The wandering mass of heavenly flame will sooner recall the yearly stars in twelve months than I would be able to recall the titles and laborious wars of earlier men.

The high renown of his ancestors and their military achievements are just too great to take together (cuncta, 18) and set in this present poem, which would be a typical panegyric strategy such as in Statius' praise of Crispinus' father's achievements in Silu. 5.2. Towards the end of the poem following the description of Piso's pastimes, the poet reiterates the point: sed prius emenso Titan uersetur Olympo | quam mea tot laudes decurrere carmina possint ('the Titan [Phaethon] would more quickly traverse measured-out Olympus than my songs would be able to cover so many subjects of praise', 209-10). The excess of subjects for which the laudandus might be praisedincluding their ancestors-is a well-known panegyric topos (cf. Theoc. Id. 7.11-12), but it is the choice of astronomical imagery which is significant. Typical panegyrics bestowed cosmic significance upon the existence and (rising) position of their laudandus, such as Pollio in Verg. Ecl. 4.5-6, or Domitian in Mart. Book 9 (9.3, for example). Sun imagery appears to have been particularly important-for example Horace in reference to Augustus (Carm. 4.2.46-7, 4.5.5-8)-and this seems to be a Hellenistic trend (see, for example, the Ithyphallic hymn of Hermocles of Cyzicus for Demetrius Poliorcetes in Powell, Coll. Alex. pages 173-5, lines 9-12=Ath. Deipn. $7.253 \mathrm{~d}) .{ }^{8}$ Thus the poet of the $L P$ uses traditional panegyric cosmic imagery in representing himself as not (yet) up to the task of fully fledged panegyric, unlike Virgil 'who with a great name strikes Olympus' (ingenti qui nomine pulsat Olympum, 231).

The poet rejects or perhaps defers the panegyric discourse that frames the deeds and nature of great men (and especially of one's ancestors) as requiring cosmic extent and having cosmic significance, and the poet focusses instead—and earnestly—on Piso's non-military exploits. When developing this topic, instead of thinking in cosmic terms the poet develops the idea of seasonality. The progression of thought is particularly important here. The emphasis on Piso's variable interest in 'more serious' (grauiora, 138 ) and 'more light-hearted pursuits' (leuiora, 139) is explained with recourse to the natural world: 'nature herself undergoes changes and, varied herself, orders the yearly cycle and unfolds the year with the changing of the leaves' (ipsa uices natura subit uariataque cursus | ordinat, inuersis et frondibus explicat annum, 145-6). A parallel is then drawn with Jupiter at the conuiuium: 'indeed, the father of the gods too puts away his fiery arms, searching for the banquet table served by Ganymede' (ignea quin etiam superum pater arma recondit | et Ganymedeae repetens conuiuia mensae, 152-3). Jupiter at a conuiuium must at some level be taken as a mirror of Piso himself, and it supports on the Olympian plane the image not of a less serious statesman but of one who engages in different activities according to the season.

The use of the seasons to characterize Piso's choice and distribution of activities helps to explain the form of the poem when, following the description of Jupiter at the conuiuium, the poet turns back to Piso's division of time between the serious and the light-hearted (162-3):

mira subest grauitas inter fora, mirus omissa paulisper grauitate lepos.

\footnotetext{
${ }^{8}$ For further discussion on solar imagery in panegyric, cf. E. Doblhofer, Die Augustuspanegyrik des Horaz in formalhistorischer Sicht (Heidelberg, 1966), 86-91.
} 
An admirable dignity is on you in the fora, and a wonderful wit when for a little while dignity is set aside.

Piso is a man for all seasons and acts appropriately at the right time. In the grand scheme of things, though, serious matters occupy the most time and light relief is only 'for a little while' (paulisper). This adverb has a certain generic affiliation; Ovid likewise signals the brief respite from martial matters that his verses on the month of March will allow for when he calls upon Mars at the opening of Fasti Book 3 to come, 'laying down his shield and spear for a brief while' (depositis clipeo paulisper et hasta, Ov. Fast. 3.1). Immediately after these lines in the $L P$, the poet describes the playful activities that have so concerned the critics as not suited to panegyric. Yet this progression is understandable given the poem's emphasis on seasonality and its signalling of a time for leuiora. Thinking in terms of the seasons opens up a space within panegyric for the playful, without ignoring or jettisoning the reality of more serious matters. This also explains the repeated use of martial language, which Steven Green sees as pointing up Piso's lack of military expertise: military concerns are ever-present and press into every aspect of the poem, but there are brief opportunities for something less serious. ${ }^{9}$ Indeed, the catalogue of games that Piso plays are all introduced by si ... forte $(163,178,185,190)$ : this is a list of possible activities to occupy his otium. It is only a potential space of play that is carved out within the poem against the more serious matters of state.

The poet's opening recusatio co-opts cosmic imagery in rejecting traditional panegyric themes and this also makes sense in terms of the authorial representation of the poet as 'young in years' ( primos ... annos, 73) and as not yet having reached his 'twentieth summer' (uicesima ... aestas, 261). Play is etymologically and sociologically linked with youth in antiquity (cf. $\pi \alpha \hat{i} \zeta$ and $\pi \alpha i \zeta \omega$; ludus and ludere) and the connection in Latin literature is made explicit in the pseudepigraphic re-imagining in the Culex of Virgil's youthful poetic endeavours that opens: lusimus, Octaui ('We played, Octavius', Culex 1). ${ }^{10}$ His young years suit a lighter, playful subject and the representation in the $L P$ of Piso as a iuuenis $(32,109,211)$, which has often been a cause for consternation, may also be intended to figure the poem's subject matter as appropriate to the age of the laudandus. ${ }^{11}$ The powerful Jupiter-like patron who is able to appreciate both serious and light affairs is thus a match for the figure of the young poet who does not vie to cover great deeds in a year-length composition, but must make a selection if he is to say anything breuiter (18). Unlike other roughly contemporary works which, as Emily Gowers has shown, focus on time's precipitous advance and the over-ripeness of the age in response to Nero's haste and the ultimate brevity of his rule, in the $L P$ an eye on the heavens offers the possibility of a more stable and measured sense of time (cf. 155-6 and 209). ${ }^{12}$ Thus, when the astronomical imagery is set against the poet's

\footnotetext{
9 Green (n. 5), 515-18.

${ }^{10}$ Peirano-Garrison (n. 6), 56-8.

${ }^{11}$ Given Piso's purported Callimachean leanings (see below), youthfulness may be a theme drawn

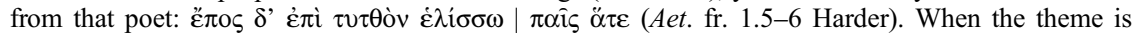
reworked by the author of the Culex, the first-person plural-lusimus-makes clear that play is for patron as well as poet.

12 E. Gowers, 'Persius and the decoction of Nero', in J. Elsner and J. Masters (edd.), Reflections of Nero (London, 1994), 131-50, at 133-9. The repeated use of numerosus $(9,66,137)$ and numerare $(70,131)$ further suggests an emphasis on measure.
} 
age, it puts the project in perspective: aiming for the stars is a noble poetic pursuit, but for our young poet such attempts are a long way off.

For Steven Green the pastimes that occupy Piso's otium are hobbies that not only come with the cultural baggage of being lowbrow, but they are decidedly un-Roman when practised outside designated periods such as the Saturnalia. ${ }^{13}$ To my mind, however, the Saturnalia provides the ideal context within which the $L P$ ought to be placed. The turn in the $L P$ from oratory and politics to otium and pastimes suits the festive tone of the Saturnalia, as does the repeated emphasis on Piso's welcoming nature and his pointed dissolving of the hierarchies of interaction in social contexts (109-19), which simulates the Saturnalia's reversal of roles. ${ }^{14}$ To be clear: I am not claiming that the poem is definitively an occasional poem for an event at the Saturnalia. What I am saying is that there is a space within Roman cultural discourse for a reversal of social structures (martial pursuits vs leisure) as exemplified by the Saturnalia, that such a reversal is operative in the $L P$ through the focus on levity, and that the theme of seasonality is the poet's way to shift the focus from the grand and the cosmic to playful matters in a way that maintains the wider importance of the ludic. (That being said, some support for a more specific Saturnalian reference might be found in the puzzling reference to the etymology of the Pisones as those who pound the moist barley at line 17: the Saturnalia was a festival associated with work in the fields, with sowing and with the harvest.) ${ }^{15}$ Representations of the Saturnalia suggest that it also involved refined and scholarly discussion as well as riddles, puzzles and mocking verses (for example Macrobius' Saturnalia). Such games are well in evidence in the $L P$.

\section{READING GAMES}

The space for play that the poet creates is filled with three of Piso's pastimes: playing the lyre, playing a ball game and playing the draughts-like ludus latrunculorum. Peirano-Garrison reads this passage as 'a jarring application of the traditional language of uirtus to utterly untraditional activities' that is simply a 'humorous variation on the standard praise of the laudandus' military achievements' ${ }^{16}$ In this section, I propose that the passage in fact constitutes a key aspect of the poem that advertises the poet's development of an appropriate topic for his age, his abilities and the brief period of otium. In this sense, I also depart from Steven Green's interpretation, which sees the poem as trying to sidestep the issue of Piso's lack of military experience by representing other activities, all the while having misgivings about this fact. ${ }^{17}$ Instead, proceeding from the observation of an unnoticed telestich and mesostich in the passage, I argue that the poet has purposefully designed a poem that privileges play, and that he signals as much to the astute reader.

${ }^{13}$ Green (n. 5), 511.

14 Although not quite the elevation of slaves to the level of masters. On the Saturnalia, cf. M.P. Nilsson, 'Saturnalia', RE 2.A.1 (1921), 201-11.

${ }^{15}$ Cf. G. Wissowa, Religion und Kultus der Römer (Munich, 1912), 204; Nilsson (n. 14), 202; H.S. Versnel, Inconsistencies in Greek and Roman Religion (Leiden, 1993), 2.164-90. On this odd etymologizing, cf. Peirano-Garrison (n. 6), 150-1 and below.

16 Peirano-Garrison (n. 6), 150 and 153.

17 Green (n. 5), 514-18. 
The poet turns to the subject of the ludus in terms that mark it out as another form of otium after the playing of the lyre and the ball game (190-208):

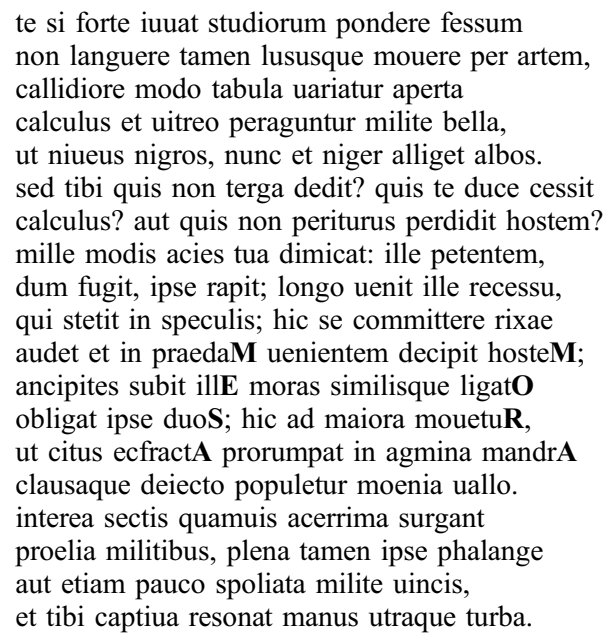

If perhaps you please, when weary with the weight of studies, to be nevertheless not inactive but to play games of skill, then on the open board in more cunning fashion a piece is moved into different positions and the contest is waged to a finish with glass soldiers, so that white checks the black pieces, and black checks white. But what player has not retreated before you? What piece is lost when you are its player? Or what piece before capture has not reduced the enemy? In a thousand ways your army fights: one piece, as it retreats, itself captures its pursuer: a reserve piece, standing on the alert, comes from its distant retreat-this one dares to join the fray and cheats the enemy coming for his spoil. Another piece submits to risky delays and, seemingly checked, itself checks two more: this one moves towards higher results, so that, quickly played and breaking the opponent's defensive line, it may burst out on his forces and, when the rampart is down, devastate the enclosed city. Meanwhile, however fierce rises the conflict among the men in their divided ranks, still you win with your phalanx intact or deprived of only a few men, and both your hands rattle with the crowd of pieces you have taken.

The game is likely to be the 'game of little soldiers', that is, the ludus latrunculorum. ${ }^{18}$ The term is not mentioned in the $L P$ but equally it is difficult to fit into the hexameter. ${ }^{19}$ Reconstructions agree that the game was played on a chequered board with a variable number of squares and with opposing black and white pieces all of the same value and that a number of moves and formations were possible: similar but not the same as modern draughts.

$M-O-R-A$ appears as a telestich at lines 200-3. While it generally means 'delay', 'deferral' or 'hindrance', in the context of the ludus latrunculorum it refers to the delaying or capturing of pieces, that is, a form of checkmate. ${ }^{20}$ As with many sophisticated acrostichs, the word appears in the text horizontally (ancipites ... moras, 201), and the multiple directionalities of reading are signalled within the

18 See K. Schneider, 'Latrunculorum ludus', RE 12.1 (1924), 980-4; U. Schädler, 'Latrunculi - ein verlorenes strategisches Brettspiel der Römer', in G.G. Bauer (ed.), Homo ludens. Der spielende Mensch (Munich, 1994), 4.47-67 and J. Richmond, 'The ludus latrunculorum and Laus Pisonis 190-208', MH 51 (1994), 164-79, with further bibliography.

${ }^{19}$ Cf. Ovid's allusion to the game at Ars am. 2.207 and 3.357.

20 Although R.G. Austin, 'Roman board games I', G\&R 4 (1934), 30 n. 3 argues against assigning the term checkmate to mora, the logic of lines 201-2 is at least that some sort of capture is at stake. 
from the centre to form phrases. ${ }^{27}$ The telestich in fact scrambles the AMOR or ROMA expected at the left-hand side of the $4 \times 4$ magic square. For the astute reader, their observational acumen mimics a good grasp on the game: anyone who notices the $M-O-R-A$ along the right-hand side of the text, just like the piece described in the poem that notices the ancipites ... moras, will be able to pre-empt attacks and turn it to their advantage. ${ }^{28}$ Moreover, just as the Tabulae Iliacae place importance on the centre of the board-'grasp the middle letter and glide whichever way you choose'

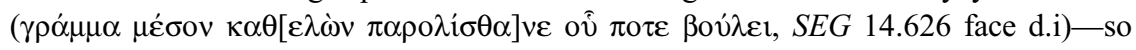
the cunning reader holds the centre when they notice the mesostich: no doubt holding the centre ground was a useful strategy in the game. ${ }^{29}$

Furthermore, there may be allusion to textual play in the contrast of black and white tokens, which makes sense for the ludus latrunculorum but may also refer to ink on papyrus. Latin references to such a contrast exist but are sparse, such as Martial's boozy poet who writes graffiti poems on walls 'with rough charcoal or crumbling chalk' (carbone rudi putrique creta, Mart. 12.61.9) and Persius' 'two-tone parchment' (bicolor membrane, 3.10) on which he writes with 'black cuttle-fish ink' (nigra ... sepia, 13), which in this case rather suggests that the parchment is faulty for not being uniformly white. Ovid's address to his book as 'not carrying white bosses on dark edges' (candida nec nigra cornua fronte geras, Tr. 1.8) marks out a contrast, but in this case the ink (of the title, at least) is a cinnabar red (cf. $T r$. 1.7). Perhaps the clearest explication is by the Neronian epigrammatist Leonides of Alexandria,

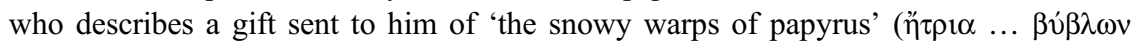

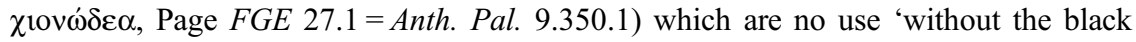

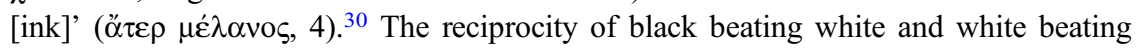

27 On magic squares, cf. M. Guarducci, "Il misterioso "quadrato magico": l'interpretazione di Jérôme Carcopino, e documenti nuovi', ArchClass 17 (1965), 219-70, at 263-70 and R.R. Benefiel, 'Magic squares, alphabet jumbles, riddles and more: the culture of word-games among the graffiti of Pompeii', in J. Kwapisz, D. Petrain and M. Szymański (edd.), The Muse at Play: Riddles and Wordplay in Greek and Latin Poetry (Berlin, 2013), 65-79, at 67-70; on the tabulae lusoriae, cf. A. Ferrua, 'Tavole lusorie scritte', Epigraphica 8 (1946), 53-73; N. Purcell, 'Literate games: Roman urban society and the game of alea', $P \& P 147$ (1995), 17-28; H. Manderscheid, F. Carboni and M. Bruno, 'Tabulae lusoriae del mondo romano: il tavoliere dei muratori di Villa Adriana, tabulae dalle Terme di Traiano a Roma e dal complesso severiano di Leptis Magna', ArchClass 62 (2011), 513-35; for the Tabulae Iliacae, cf. M. Squire, The Iliad in a Nutshell: Visualizing Epic on the Tabulae Iliacae (Oxford, 2011), 197-210.

${ }^{28}$ Two further parallels may also be pertinent. At Ars am. 3.473, Ovid advises women in letter-writing to 'write back after a brief delay' ( postque breuem rescribe moram) in a passage which precedes a telestich spelling out $A-M-O-R$ (or $R-O-M-A$ ); cf. M. Hanses, 'Love's letters: an Amor-Roma telestich in Ovid, Ars Amatoria 3.507-10', in P. Mitsis and I. Ziogas (edd.), Wordplay and Powerplay in Latin Poetry (Berlin, 2016), 199-211, at 202. It may be that our poet, if he has read Ovid, is taking the advice to 'rewrite mora' literally with his own telestich. The second text is Aen. 4.399-402, which J. Katz, 'An acrostic ant road in Aeneid 4', MD 59 (2008), 77-86 argues windingly encodes formica into the text in echo of the passage's ant metaphor. For my purposes, agmen (4.404) there seems to stage the march across the page in the same way that the pieces on the board form agmina (203), and perhaps the letters on the page.

${ }^{29}$ See also $I G$ 14.1285.1, face B.I. For the reconstruction of the lacuna, cf. Squire (n. 27), 205; alternative readings do not affect my argument. The importance of holding the centre might also be related to the $5 \times 5$ magic square, SATOR AREPO TENET OPERA ROTAS (perhaps: 'The sower Arepo holds the work by the wheels'), where the central cross is 'held' by TENET. See Guarducci (n. 27), 219-26 and the bibliography in W.O. Moeller, The Mithraic Origin and Meanings of the Rotas-Sator Square (Leiden, 1973).

${ }^{30}$ A similar mention is found later in Ausonius where the solver of riddles is able to interpret 'Cadmus' little dark girls, Melo's white page, the marks of the dark cuttlefish' (Cadmi nigellas filias | Melonis albam paginam | notasque furuae sepiae, Epist. 14.74-60). In other words, the solver reads. 
black on these terms might be understood as the various ways in which the page and the ink may be configured: one way, one reading is successful, in another way, another. The poet goes on to call his offering to Piso a pagina (214). This is perfectly understandable in reference to a Latin poem (see, for example, Ecl. 6.12, Culex 26), but once the telestich has been observed a further sense may be inferred: according to Pliny the Elder (HN 17.169), pagina had the technical sense of a row of vines set out in a square of $4 \times 4$. The pagina is already a lattice on which word games might be played. These suggestions aside, though, it is clear that the lettered board games of the squares and tablets, and their playful emphasis on the spatiality of text, lay the groundwork for the combination of board-game description and telestich and mesostich observable in the $L P$. The poet of the $L P$ takes the description of a board game in the text as an opportunity to make the text itself a letter-game on the model of contemporary Roman board games.

To situate the passage within the poem further, I want to consider briefly the Neronian poet Leonides of Alexandria, mentioned above. ${ }^{31}$ One epigram of his plays out in nuce a similar combination of play and cosmic themes to that found in the $L P$ (Page FGE 2 = Anth. Pal. 6.322):

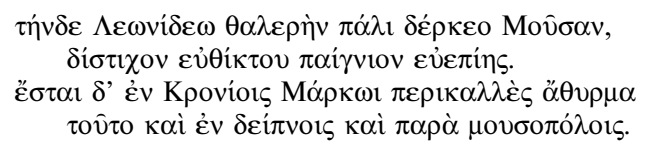

Look again at this fresh Muse of Leonides, a two-line plaything of clever eloquence. This will be a very fine toy for Marcus at the Saturnalia, both at dinners and among the servants of the Muses.

The epigram is self-conscious by referring to its nature as a $\pi \alpha$ irviov, and the use of

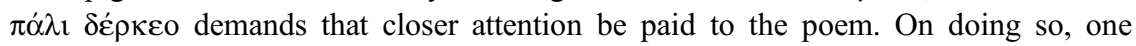
discovers that the poem is isopsephic, a form of epigrammatic composition where couplets add up to the same value when the individual letters are read as numbers. ${ }^{32}$ In this case, what the text asks the reader to look at is the second couplet only, where each line adds up to 3,108 . As well as being a literary game, it is one for the Saturnalia and specifically for convivial aspects of it. While the description of Leonides' Muse as $\theta \alpha \lambda \varepsilon \rho \eta \dot{v}$ has generally been passed over without comment, it responds to the agricultural significance of the Saturnalia: this is a poem that is 'fresh', 'blooming' or 'in season'. Beyond its isopsephy, however, the opening couplet asks the reader to pay close attention to a couplet. An educated reader will note that in the second couplet $\pi \varepsilon \rho \iota \alpha \alpha \lambda \lambda \grave{\varepsilon} \varsigma \not ̈ \theta v \rho \mu \alpha$ is a collocation found elsewhere in Greek poetry only in Apollonius' description in the Argonautica of Zeus's plaything given to Eros as a bribe, which is figured as a divine globe or comet (Ap. Rhod. Argon. 132 and 131-41). ${ }^{33}$ It is an astronomical gift for Marcus, the sort with which Eros and Zeus used to play. The epigram manages to style itself as an occasional piece that at the same time has greater astronomical significance for the keen reader.

${ }^{31}$ For a discussion of Leonides' epigrams, cf. G. Nisbet, Greek Epigram in the Roman Empire: Martial's Forgotten Rivals (Oxford, 2003), 202-8 and N. Livingstone and G. Nisbet, Epigram (Cambridge, 2010), 119-21.

32 On Leonides and his isopsephy, cf. D.L. Page, Further Greek Epigrams (Cambridge, 1980), 503-14.

33 I intend to explore Leonides' allusion in this epigram in more detail elsewhere. 
In contrast to Leonides at the court of Nero, who uses his paignion to playfully place the skies in the reader's hands, cosmic themes are programmatically incompatible with the focus of the $L P$ on play. ${ }^{34}$ Some decades later, Martial will write of Domitian's return from his successful Danubian campaign with alacrity: Phosphore, redde diem: quid gaudia nostra moraris? ('Phosphorus, bring back the day, why do you delay our joy?', Mart. 8.21.1). ${ }^{35}$ The cosmos works against the hopes of the people: the cycles are too slow and the dawn of Caesar's return is too far away. For the poet of the $L P$, the movement of the stars is equally long and the cycles equally great, but they rather create the space within which to display the status and deeds of great men (that is, priscorum titulos operosaque bella, 21). In contrast to Martial's martial eagerness in the face of delay (cf. moraris), the poet of the $L P$ embeds at the climax of his description of Piso's otium, at the heart of his list of ludi, that self-same 'delay' (mora, M-O-R-A) of serious matters. If, as the poet suggests, the life of a Roman politico is mostly serious and he only has the briefest space for leisure, then the description of the games works to dilate the time allowed for leisure, and the letter games within the ludus latrunculorum passage serve to delay the reader further. While the typical patron's time is monopolized by serious affairs, in other words, the $L P$ demands of the reader a dedicated focus on play. As will become clear, it is a strategy aimed at Piso in particular.

\section{THE PLAYFUL PATRON}

Gottfried Mader proposed that the poet of the $L P$ develops a clear commerce of praise, where the praise of Piso is politically strategic but also raises the profile of the poet and secures patronage in return. ${ }^{36}$ What I wish to propose in this section is that taking account of the temporal recalibrations discussed in the first section and the delay generated by play proposed in the second section clarifies this interaction and reveals a poet producing a specifically playful type of praise poetry for his specifically playful patron.

So far, I have described the text's playfulness for the general ancient reader, though there are reasons to suppose that this playfulness is aimed at the poet's patron directly. In broad terms, Piso is described as a man of verbal sophistication. In the opening lines the poet addresses Piso as someone 'who equals such great ancestors in intellect' (qui tantis animum natalibus aequas, 12; see also 26). This is then followed by a channelling of the traditional subject of panegyric away from war to the law court, with the poet leaving behind, and being unable yet to rise to, the heights of recounting Piso's ancestry and 'the tiresome wars of old men' (priscorum ... operosaque bella, 21). It is instead Piso's intellect that continues to be the focus (57-64):

nam tu, siue libet pariter cum grandine nimbos

densaque uibrata iaculari fulmina lingua,

seu iuuat adstrictas in nodum cogere uoces

\footnotetext{
34 And even in the Imperial reader's hand (as in Page, FGE 32, a celestial globe for Poppaea Augusta) in the same way that Nero's 'starry colossus' in Martial 'sees the stars close up' (sidereus propius uidet astra colossus, Spect. 2.1).

${ }^{35}$ For the political and ludic nature of this epigram, see L. Watson, 'Martial 8.21, literary lusus, and Imperial panegyric', in F. Cairns and M. Heath (edd.), PLLS 10 (1998), 359-72.

${ }^{36}$ G. Mader, 'Re-presenting Piso: poetic and political agenda in the Laus Pisonis', CW 106 (2013), $621-43$, at $638-9$.
} 
et dare subtili uiuacia uerba catenae, uim Laertiadae, breuitatem uincis Atridae; dulcia seu mauis liquidoque fluentia cursu uerba nec incluso sed aperto pingere flore, inclita Nestorei cedit tibi gratia mellis.

For whether it be rain along with hail and repeated thunderbolts that you choose to hurl with whirling tongue, or whether you please to condense compact expressions in a period and lend enduring words to the graceful texture of your speech, you surpass Ulysses' force and Menelaus' brevity; or if with flowers of speech, not concealed but open, you prefer to embellish sweet words as they flow on their clear course, the famous charm of Nestor's honeyed eloquence yields place to you.

Piso is a picture of oratorical poise and power; he wields words like Jupiter, and holds his own against the best of Homeric speakers. For Steven Green, these descriptions form a nexus of military images that ironically underscore Piso's lack of military experience; while Jupiter's verbal thunderbolts are thought to overdo the comparison of the laudandus with Jupiter, the Homeric models are seen to differ from Piso in that they are accomplished warriors. ${ }^{37}$ Yet in both cases it is probable that the poet has stylistic considerations in mind. The triad of Menelaus, Nestor and Odysseus is found in discussions of rhetorical style, where they stand for the plain, flowery and grand style respectively. ${ }^{38}$ The poet represents Piso not simply as good at rhetoric but able to range over its various styles. Likewise, the slippage between the accomplished speaker and metaphorical brightness may be both rare and exaggerated to Green, but the imagery is perfectly understandable when read against [Longinus]' On the Sublime, where the language of being struck by the bolt of sublime poetry or oratory is ubiquitous. ${ }^{39}$

Similar imagery occurs a number of lines later, once the poet has transitioned from Piso's declamatory skills to his poetic compositional skills (94-6):

hinc solido fulgore micantia uerba impleuere locos, hinc exornata figuris aduolat excusso uelox sententia torno.

Here words sparkling in compact splendour have filled out his choice passages; here, decked out with tropes there flies from the moving lathe a swift epigram.

The poet resumes the image of shining verbal skill and taps into a further store of metaphors with the image of the lathe, recognizable from representations of verbal

${ }^{37}$ Green (n. 5), 508 and 510.

38 E.g. Cic. Brut. 40 and 50; Quint. Inst. 12.10.64; Sen. Ep. 40.2; Fronto, De eloqu. 1.5; cf. A. Seel, Laus Pisonis: Text, Übersetzung, Kommentar (Erlangen, 1969), 64-6 and B. Gibson, Statius, Silvae 5 (Oxford, 2006), 309-11. The foundational passages are Il. 3.213-23 and (probably) Il. 1.249. The poet's description of Menelaus' subtle style and of the forceful Odysseus is echoed in Quintilian's description of the three styles, where the 'first is subtle' (unum subtile, Inst. 12.10.58) and the third 'carries the judge away despite his struggling' (torrens iudicem uel nitentem contra ferret, Inst. 12.10.61). This may affect the dating of the $L P$, but such imagery in any case pre-dates the Institutio Oratoria.

${ }^{39}$ Cf. e.g. 34.4. The question of the date is of course pertinent; see D.A. Russell, 'Longinus': On the Sublime (Oxford, 1964), xxii-xxx and, contra, M. Heath, 'Longinus, On Sublimity', PCPhS 45 (1999), 43-74. On most conservative estimates, it would be perfectly possible for our author to have read the work. By the same token, [Longinus]' imagery of style is probably not entirely his own invention; the image of the bolt of genius probably had existing currency. Think, for example,

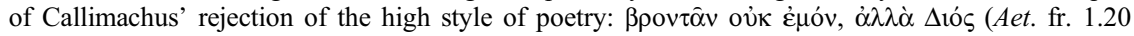
Harder). 
skill in Aristophanes, Plato, Propertius and Horace. ${ }^{40}$ (Since Piso is suggested to be of a Callimachean persuasion, the similar language of Crinagoras' description of

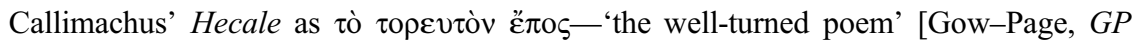
$11.1=$ Anth. Pal. 9.545.1] - may also be at play. ${ }^{41}$ In other words, then, the poet represents Piso as a man of high literary abilities and taste through standard imagery of literary quality and style. What is more, the mention of words filling the locos with 'compact splendour' at lines 94-5 could gesture to his favouring of letter games, where the closeness of letters and the handling of the text in spatial terms enables their discovery: is Piso's personal style one which has an affinity with this poet and his textual games?

I think that the answer is yes. A series of further textual allusions spanning through the text and centred on the Calpurnii and on Piso figures the telestich as a particularly apt game for him. In the opening lines of the poem, the poet etymologizes the cognomen Piso (14-17):

nam quid memorare necesse est, ut domus a Calpo nomen Calpurnia ducat claraque Pisonis tulerit cognomina prima, humida callosa cum 'pinseret' hordea dextra?

What need to record how the Calpurnian house derives its name from Calpus and won its first famous surname of Piso for pounding ( $i[n]$ seret) the moist barley with hard-skinned hand?

The mention of such a rustic explanation at the opening of the $L P$ could be understood to undermine the (supposed) lofty aims of the poet. ${ }^{42}$ What is important to highlight, though, is that it emphasizes that the cognomen Piso comes from the action of the right hand (dextra). The word occurs twice more in the $L P$, both times at the end of the hexameter (152-4 and 183-4):

ignea quin etiam superum pater arma recondit

et Ganymedeae repetens conuiuia mensae

pocula sumit ea, qua gessit fulmina, dextra.

Yea, the Sire of the Gods stores away his fiery weapons, and, seeking again the banquet at the table served by Ganymede, he grasps the goblet in the right hand wherewith he wielded the thunderbolt.

et nunc uiuaci scrutaris pectora dextra, nunc latus aduersum necopino percutis ictu.

now your vigorous right hand lunges at his breast, now your unexpected thrust strikes his exposed flank.

It is used to describe Jupiter at a conuiuium who wields the thunderbolt and the wine cup, in a new take on the panegyric fashion of comparing the laudandus to the god. ${ }^{43}$ It is then used to describe Piso's own competition in arms after the description of his lyre-playing skills and immediately before the description of playing the ludus

40 Ar. Thesm. 54; Pl. Phdr. 234e; Prop. 2.34.43; Hor. Ars P. 290.

${ }^{41}$ For Callimacheanism after Ovid, see Sullivan (n. 3), ch. 2; for Callimachus in the $L P$ specifically, see Green (n. 5), 512.

42 Peirano-Garrison (n. 6), 150-1.

${ }^{43}$ For more on that imagery, see Mader (n. 36), 623 and Green (n. 5), 513. 
latrunculorum. The use of dextra thus connects the meaning of Piso's name both to his prowess in combat and to his analogous position on the divine plane. That the poet offers a telestich rather than an acrostich suits a patron who in family and in aspiration pays attention to the right hand and (the poet might hope) to the right-hand side. ${ }^{44}$

Piso, moreover, is figured as having a particular skill for observing what may be hidden and it is this ability that makes him the ideal patron (223-6 and 253-9):

sublimior ibo

si famae mihi pandis iter, si detrahis umbram.

abdita quid prodest generosi uena metalli,

si cultore caret?

I will proceed more loftily, if you are now opening for me the path of fame, if you are removing the shadow (of obscurity). What profits the hidden vein of precious metal, if it lacks the miner?

$$
\text { tu, Piso, latentem }
$$

exsere. nos humilis domus, at sincera, parentum

et tenuis fortuna sua caligine celat.

possumus impositis caput exonerare tenebris

et lucem spectare nouam, si quid modo laetus

adnuis et nostris subscribis, candide, uotis.

May you, Piso, bring to the light one who is obscure. The home of my sires, humble but true, along with its slender fortune hides me in its own darkness. I can clear my head of its enshrouding burden, I can behold fresh light, if you, my fair-souled friend, do but cheerfully approve and support my aspirations.

The apostrophe to Piso follows on from the outline of his pastimes, and the subject turns towards Piso as a potential patron of the poet. In the intervening lines (230-53), the poet makes a parallel with Maecenas' patronage of not just Virgil but of Varius and Horace too. Piso, like a new Maecenas, has the ability to mine seams of rock for precious metal and to illuminate and so banish the Virgilian umbrae of poetic anonymity (cf. 233). Patronage need not be expressed through a discourse of hiddenness; in Virgil and Propertius, for example, the discourse is one of autonomy and coercion, of the song commanded (or not): non iniussa cano ('I sing things not uncalled for', Ecl. 6.9); sequamur $\mid$... tua, Maecenas, haud mollia iussa ('I follow, Maecenas, these not so easy commands of yours', G. 3.40-1); quis te | carminis heroi tangere iussit opus ('who ordered you to undertake a work of heroic songs?', Prop. 3.3.15-16)..$^{45}$ The choice, then, is deliberate. Whatever else it achieves_-increasing Piso's agency, for instance-hiddenness is a theme that has specific valency for works with letter play. Immediately preceding his $\Lambda \mathrm{E \Pi TH}$ acrostich, Aratus explains his Stoic outlook (Phaen. 768-71):

$\pi \alpha ́ v \tau \alpha \gamma \grave{\alpha} \rho$ o $\pi \omega$

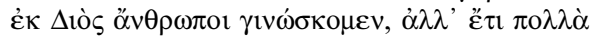

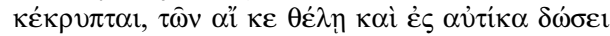

Zev́ৎ

44 The influence of Aratus may also be suspected in the focus on 'the right'. At the opening of the Phaenomena, Zeus is said to 'give favourable signs' where $\delta \varepsilon \xi i \dot{\alpha} \sigma \eta \mu \alpha i v \varepsilon 1$ (6) is verse initial. The poet of the $L P$ takes this astrological-cum-acrostich model seriously and gives signs that are indeed $\delta \varepsilon \xi ı \dot{\alpha}$.

${ }^{45}$ Cf. L. Roman, Poetic Autonomy in Ancient Rome (Oxford, 2014), passim and especially the introductory remarks at 11-24. 
For we men do not yet have knowledge of everything from Zeus, but much still is hidden, whereof Zeus, if he wishes, will give signs anon;

Aratus primes his readers to look for signs and to understand that many things in the world (such as how it works) are still hidden. The poet of the $L P$ grafts this dynamic of disclosure onto the figure of Piso who is able to bring to light what is hidden and 'read the signs' like Aratus' masterful reader for whom Zeus's revelations lay open.

Rather than the letter games and the allusion to the telestich undermining the $L P$ as a serious panegyric of praise, what emerges is a poet who purposefully ties his pitch for Piso as his patron to the literary game: his ability to uncover the telestich will figure Piso as the ideal patron to uncover the poet's hidden talent. More than that, he takes on the acumen and revelatory powers that, according to Aratus, were once the purview of Jupiter. The fact that the name of the Calpurnii 'shines among the Roman families' (Romanas inter fulgentia gentes, 4) and that Piso's words 'sparkle with compact splendour' (94) further prime them as suitable for bringing such hidden words to light. ${ }^{46}$ These two forms of uncovering may be encapsulated in subscribis, which formally means 'give one's support to', but which could also refer to the noting down or underlining of something within the text: if Piso notices the telestich, he by implication 'takes note' of the poet's uota. ${ }^{47}$ The poet-patron dynamic in this text, in short, is predicated on play.

\section{PRAISE AND PLAY}

The $L P$ is not the panegyric scholars want it to be. It avoids and sidelines military exploits, and dresses non-military activities in martial language. It is presented as if it is written by a young poet who still needs to perfect his craft. If one were to diagnose a reason for the largely negative approach to the $L P$, it may well lie in the fact that many commentators assume that the poet really is as young as he says. ${ }^{48}$ These two aspects of the poem, however, are intentional: the poet chose his themes as much as his representation of the poet figure as a youth. Playfulness and youth, as I have suggested by the parallel with the Culex, go together. Rather than the $L P$ constituting a political mismatch - a failed panegyric by a naïve young poet — this is a different sort of poem with manifestly different aims. The poet has played a strategic game and set at the climax of his catalogue, in the lines describing the ludus latrunculorum, a delay that

\footnotetext{
${ }^{46}$ Further instances are listed at Mader (n. 36), 639 n. 40. This is also a positive application of the solar imagery which appears in other panegyric texts (see above) but which is generally avoided by the $L P$ poet. Their shining nature is what ultimately enables them to uncover the virtues of this poet hidden in the umbrae - and perhaps the telestich hidden in the text.

${ }^{47}$ Cf. T. Kearey, 'Two acrostics in Horace's Satires (1.9.24-8, 2.1.7-10)', CQ 69 (2020), 734-44, at 740-1, who argues that Horace in a similar manner uses praescribe (Sat. 2.1.5, 'make a ruling' but also 'write out in the first letters') to signal his own acrostic.

${ }^{48}$ Cf. e.g. Duff and Duff (n. 1), 289: 'The Panegyric on Piso, by a young poet who pleads poverty but covets literary fame in preference to wealth, is addressed to one Calpurnius Piso'; or Mader (n. 36), 622: 'Its anonymous author is an aspiring but impoverished young poet in search of a patron-and panegyric flattery of Piso doubles crucially as an attempt to attract the great man's attention by providing a sample of the would-be client's verse.' Only slightly more circumspect is Green (n. 5), 498: 'All that the text itself offers, if we are to take it at face value, is that its poet is very young, in that his "twentieth summer has not yet arrived" (261): this would make him either eighteen or nineteen years old, depending on whether or not the speaker is counting inclusively.'
} 
spreads out over the space of the text. The poet makes the audience stop, reread, reconfigure the text at the point at which they are furthest away from the traditional world of panegyric. He embeds a sign at the core of his poem that underscores it as a panegyric of play: just the kind of panegyric that suits a budding poet yet to find his patron. ${ }^{49}$ For the discerning reader, that is, the $L P$ offers an explanation for its combined choice of patron and subject matter by lingering over the ludic.

The remaining question is what to make of the poem as a whole. Is it a parodic simulation of puerile attempts at poetic praise or a template for a new panegyric mode? My proposition is that the telestich's emphasis on delay within the description of Piso's otium is a self-reflexive marker of the changing role of playful and non-serious poetic practices vis-à-vis the political profile of the patron. The point can best be made by setting the $L P$ against both earlier and later works. On the one hand, Augustan poems employ word games to present a perhaps highly familiar account of the poet's patronal predicament. As Talitha Kearey has recently exposed in an illuminating article, Horace at the opening of his second book of Satires (2.1.7-10) encodes otia into his text as an acrostich, following Virgil's otia telestich at the end of his Georgics (4.562-5). She observes how the two poets weave otia into their texts precisely at the point where the pressure of producing panegyric becomes programmatic: otium was Virgil's refuge from having to address Caesar and his thundering war (4.560-1), and otium is Horace's alternative to recounting unvanquished Caesar (Caesaris inuicti res dicere, 2.1.10). ${ }^{50}$ For these poets, the creation of acrostichs demands labour, craft and practice which is only made possible by marking out for oneself a little otium, and as a consequence the studied use of one's otium does not leave much time for panegyric pursuits. ${ }^{51}$

In works from the late first century C.E., on the other hand, there is a notable development in the presence of a ludic mode of poetry within the prestige arena of the Roman elite. As Matthew Roller has advised in an analysis of Pliny's description of his own otium and production of occasional and light works, the 'appropriation and display of Catullan polymetric verse must be seen as one of a number of emerging strategies for reputation-building in the early empire, strategies which are "politically" significant in both senses of the word'. ${ }^{2}$ The political nature of the trivial and frivolous in relation to one's patron can be set in high relief by two works addressed to Domitian. Martial's prose preface justifying the dedication of his eighth book of epigrams to Domitian-the first explicitly to be so directed-charts clearly the important function of commingling serious and light topics for a patron: quam quidem subinde aliqua iocorum mixtura uariare temptauimus, ne caelesti uerecundiae tuae laudes suas, quae facilius te fatigare possint quam nos satiare, omnis uersus ingereret ('these same [compositions], however, I have tried to vary now and again with a certain

${ }^{49}$ Is it even too cynical to think that, within the fiction of ancient poetic careers, the telestich is there to test the waters and to gauge whether (a) Piso has the 'enlightening' reading skills of a Maecenas? No one would want to compose a whole epic only to find their patron a poor appreciator of poetry ...

${ }_{50}$ Kearey (n. 47), 743.

51 Ovid's telestichs will also have to be factored into any further analysis of the politics of Augustan poetry's wordplay. K. Mitchell, 'Ovid's hidden last letters on his exile - telestichs from Tomis: postcode or code?', CCJ 66 (2020), 144-64-which came to my attention too late to be fully incorporated into this discussion-has argued for a political positioning of Ovid's $T-O-M-I S$ telestichs in passages of the Fasti and the Tristia. See also K. Mitchell, 'Acrostics and telestichs in Augustan poetry: Ovid's edgy and subversive sideswipes', CCJ 66 (2020), 165-81.

52 M. Roller, 'Pliny's Catullus: the politics of literary appropriation', TAPhA 128 (1998), 265-304, at 300 . 
combination of joking, lest each verse heap up our praise of your celestial modesty which would more easily be able to tire you than satiate us', 8 Praef. 6-10). Just as in the $L P$, here the trivial helps offset and break up the continual cosmic concerns of the emperor by dropping in works of comic relief. The reality of the political contamination of otium can be seen in Statius' Siluae 1.6, which describes a Saturnalia festival hosted by Domitian. Its hendecasyllables and the initial summoning of 'laughing Jest and wanton Wits' (ridens Iocus et Sales proterui $\mid$ adsint, 1.6.6-7)—so reminiscent of Catullus' irreverent use of the metre and predilection for jocular urbanity-present the license of the festival..$^{53}$

In both cases, though, Domitian's tight grasp on cultural output also shapes the discourse of play. Martial must redraw the ethics of the Catullan persona by impressing on Domitian that, even though the severest of men composed epigrams seeming like mimes, his works in the present book are not too lasciuus (8 Praef. 10-14). ${ }^{54}$ Similarly, Statius' Saturnalia really only offers a veneer of liberty that masks a highly stage-managed exercise of license and otium that is controlled and dictated by Domitian (the festival, after all, is the Saturnalia principis, Silu. 1.6.82). ${ }^{55}$ By the Flavian period, in other words, not only will the nugatory be co-opted as an additional means of competing for elite prestige, but play will be pulled into the orbit of patronage at the highest level: pandering to the princeps. Whether this is panegyric parading as parrhessia (that is, free-speech) or vice versa, it is clear that the jocular, the licentious, the light and the otiose will no longer be separate from the negotium of political life but an additional cultural site through which power dynamics might be mediated.

When it comes to letter games in particular, the politics of this play will reach its pinnacle with the panegyric poems sent to Constantine by Publilius Optatianus Porfyrius, (better) known as Optatian, in the early decades of the fourth century C.E. His book, Panegyricus, was an anthology of metrically experimental poems, picture poems, poems containing acrostichs, telestichs and mesostichs as well as so-called carmina cancellata. These gridded poems of 35 letters both along and across can be read in the traditional linear manner but also open up a chequer-board space within which additional images are to be found highlighted in different coloured inks, and which in turn spell out whole new words and sentences. Despite the critical neglect of these fascinating poems that toy with words and images, a new industryspearheaded in Anglophone scholarship by Michael Squire-is beginning to plot out just how sophisticated these texts are at responding to the literary, political and religious exigencies of the early fourth century C.E. ${ }^{56}$ Following such reappraisals, there can be no doubt that by this era letter games extend beyond the world of Roman otium and are

${ }^{53}$ Cf. L. Morgan, Musa Pedestris: Metre and Meaning in Roman Verse (Oxford, 2010), 63-73 for the Catullan overtones of hendecasyllables.

${ }^{54}$ For the Catullan background, cf. C. Schöffel, Martial, Buch 8: Einleitung, Text, Übersetzung, Kommentar (Stuttgart, 2002), 70-2.

${ }^{55}$ For the tension between public licence and the power of the princeps at this Saturnalia feast, see C. Newlands, Statius' Silvae and the Poetics of Empire (Cambridge, 2002), 238-52 and for parallel political readings of Martial's Saturnalian settings, see V. Rimell, Martial's Rome and the Ideology of Epigram (Cambridge, 2008), 140-4 and passim.

${ }^{56}$ For ease of reference, a new typographical setting of the poems, a series of illuminating essays covering the literary inheritance, religious significance and political import, and an extensive and wide-ranging bibliography can all be found in M. Squire and J. Wienand (edd.), Morphogrammata / The Lettered Art of Optatian: Figuring Cultural Transformation in the Age of Constantine (Paderborn, 2017). Still fundamental, though, is G. Polara (ed.), Publilii Optatiani Porfyrii Carmina, 2 vols. (Turin, 1973). 
politically engaged compositions. So influential was Optatian's visual-cum-verbal virtuosity, Jerome reports (Chron. on 329), that it secured his return from exile. ${ }^{57}$

My concluding claim, therefore, is that the telestich and the mesostich across the textual space of the ludus latrunculorum, and the wider integration in the LP of the playful and the political in appealing to a Piso, are a distant ancestor of Optatian's own textual games with chequer-board poems proffered to Constantine rather than a relative of Virgil's telestich and Horace's acrostich telling of otia. One line of scholarship has been that the $L P$ marks a shift in the traditional poetry of the political elite in response to their progressive disempowerment: play takes the place of power. ${ }^{58}$ What the $L P$ demonstrates, however, is that the patron is set in a world of otium not as a surrogate for political participation but as an additional means through which both the poet's and the patron's position might be negotiated and their prestige enhanced: the $L P$ sees the beginnings of a Roman political discourse encroaching on the value of the trivial and the boundaries of otium. Before Statius and Martial's introduction of the licentious and free, the irreverent and Catullan into the sphere of Domitian, and well before Optatian's crosswords for Constantine, the Claudian or Neronian $L P$ and its telestich are already pressing the alert reader to ponder over the seriousness of such games and to acknowledge them as a fundamental aspect of a new kind of panegyric. In short, the $L P$ not only represents but also seeks to thematize poetry that makes play political.

Trinity Hall, Cambridge

MAX LEVENTHAL maxleventhal@msn.com

${ }^{57}$ For discussion, cf. M. Squire, 'Optatian and his lettered art: a kaleidoscopic lens on Late Antiquity', in M. Squire and J. Wienand (edd.), Morphogrammata / The Lettered Art of Optatian: Figuring Cultural Transformation in the Age of Constantine (Paderborn, 2017), 57-9.

${ }^{58}$ Cf. H. Leppin, 'Die Laus Pisonis als Zeugnis senatorischer Mentalität', Klio 74 (1992), 221-36 with further references and discussion at Mader (n. 36), 624 n. 10. 